\title{
Isolation of Potentially Pathogenic Bacteria from Public Service Cars Door Handles
}

\author{
Sleiman Iskandar ${ }^{1}$, Amir Saif ${ }^{1}$ and Tarek Nawas ${ }^{1 *}$ \\ Natural Sciences Department, Lebanese American University, Beirut, Lebanon \\ *Corresponding author
}

\section{A B S T R A C T}

\section{Keywords \\ Publictransport, Service cars, Door handles, Bacterial contaminants, Coagulase negative staphylococci, Staphylococcus aureus \\ Article Info \\ Accepted: \\ 10 November 2018 \\ Available Online: \\ 10 December 2018}

The possible bacterial contamination of the door handles of public "service" cars working within the city of Beirut, the capital of Lebanon, was investigated. Door handles from 22 cars were sampled and cultured on multiple culture media. From the 22 samples, 29 different isolates were grown and identified. Of these, $17(58.6 \%)$ were Staphylococcus aureus, 11 (37.9\%) were coagulase-negative Staphylococcus spp. and $1(3.5 \%)$ was Klebsiella oxytoca. Of the 22 door handles sampled, $16(72.7 \%)$ grew Staphylococcus aureus, 12 (54.5) grew coagulase-negative Staphylococcus spp., 1 (4.5\%) grew Klebsiella oxytoca and $2(9.0 \%)$ did not grow any organism. As the isolated organisms were involved in nosocomial and community acquired infections, their presence poses a threat, especially to passengers who might be immunocompromised. Regular cleaning procedures are suggested to protect the users of these door handles from the possible dangers associated with these organisms.

\section{Introduction}

The hands are probably the most exposed organs, of the human body, to environmental bacterial contamination. They are the central organs for the physical manipulation and control of the surrounding environment. It is impossible for the hands to be free of microorganisms, that are why they serve as a means of transmission of microorganisms from an individual to another and from one place to another. In addition to the microorganism of the body's normal flora, the human hands usually harbor transient microorganisms contracted from the environment (Dodrill et al., 2011). The most prominent bacteria present on every healthy hand include: Staphylococcus epidermidis, Corynebacterium spp, Micrococcus spp., in addition to some members of the family Enterobacteriaceae (Leyden et al., 1991). Transient Pathogenic bacteria that are possible to be present on the hand include: Salmonella typhi, Escherichia coli, Pseudomonas aeruginosa, Proteus mirabilis, Klebsiella spp., Enterobacter spp., Streptococcus spp. and Staphylococcus aureus (Orskov et al., 1997). Some of these transient bacteria can be sometimes notorious pathogens that may lead to acute or even chronic illness. 
Scientific studies have revealed that commonly used surfaces such as telephones, computers, books, door handles, ATM and vending machines, desks and numerous other items can be a major source potentially pathogenic bacteria (Reynolds et al., 2005; Nworie et al., 2012; Memišević et al., 2013;Joshaline, 2014; Hamze and Na'was, 2015; Nwankwo and Chinyeaka, 2015; Sani, 2016; Dakroub and Nawas, 2017). As the hands touch these items continuously, it is no wonder that some of these organisms end up as transient flora of the hands.

In Lebanon, a very common means of public transportation is the "service" car. The owners of these cars are given the permission to transport different passengers simultaneously from one place to another within big cities. A miniatured model of a bus, carrying a smaller number of passengers that are dropped and picked up along the way. Previous studies investigated the presence of microbes, but inside automobiles. A study investigated the microbial population present on the interior surfaces of a car, for the purpose of designing automobile interior surfaces that can resist colonization by microbes (Stephenson et al., 2014). Another study investigated the bacterial contamination of hand touched surfaces in buses, trains, stations, and other public areas London (Otter and French, 2009). The literature reviewed, however, did not reveal any studies about the possible contamination of car door handles, especially cars that are extensively used by many passengers during the same day, a reason why this study was designed to isolate and definitively identify any bacterial contaminants of the door handles of "service" cars working in the city of Beirut, the capital of Lebanon.

\section{Materials and Methods}

\section{Sample collection}

A total of twenty-two (22) service car door handles were sampled in the study. The cars were chosen to work in different parts of the city (Beirut). The samples were collected using sterile cotton swabs moistened and inserted within sterile trypticase soy broth (TSB) tubes. After pressing the swab against the inner side of the tube, to remove the excess broth, the samples were collected by rubbing the swab, on the door handles, in a tri-directional manner: up/down, left/right and diagonally, while rotating the swab, to ensure that each door handle was properly sampled. The swabs were then reinserted in the tube and immediately transported to the microbiology laboratory within no more than 30 minutes. The sampled door handles were cleaned with alcohol to make sure that the broth was completely removed.

\section{Processing of the samples}

Upon arrival to the microbiology laboratory, each swab was immediately used to heavily inoculate four types of culture media: Trypticase soy agar (TSA), MacConkey Agar(MA), Mannitol salt agar (MSA) and Cetrimide agar (CA) plates. The inoculated plates and the TSB tube, containing the tip of the swab, were incubated for $18-24$ hours at $35^{\circ} \mathrm{C}$. After 24 hours, the TSB broth was vortexed and used to inoculate a new set of the same four types of media and these were also incubated for 18-24 hours at $35^{\circ} \mathrm{C}$. Each type of colony growing on any of the ( 2 sets of) inoculated plates, was then isolated on a TSA plate for definitive identification.

\section{Identification of the isolates}

Gram staining of the isolates confirmed they were all Gram-positive cocci except for one isolate which was a Gram negative bacillus. The isolated organisms were identified by standard biochemical methods (Cowan and Steel, 1974) and the identity of the Gram-negative bacillus was confirmed using the API 20E test strips (BioMerieux - France), as it was found to be members of the family Enterobacteriaceae. 


\section{Results and Discussion}

The results of the study are summarized in Table 1. From the 22 service cars door handles sampled, 2 did not grow any organism, while the remaining 20 grew 29 different organisms. Of these isolates, $17(58.6 \%)$ were identified to be Staphylococcus aureus, 11 (37.9\%) were coagulase-negative Staphylococcus spp. and 1 (3.5\%) was Klebsiella oxytoca. Of the 22 door handles sampled, $16 \quad(72.7 \%)$ grew Staphylococcus aureus, 12 (54.5) grew coagulase-negative Staphylococcus spp., 1 (4.5\%) grew Klebsiella oxytoca and 2 (9.0\%) did not grow any organism.

Table.1 The bacteria isolated from each of the different samples of the door handles of the public "service" cars included in the study. NG: No growth

\begin{tabular}{|c|c|}
\hline Sample \# & Isolates \\
\hline 1 & Coagulase-negative Staphylococcus sp \\
\hline 2 & NG \\
\hline 3 & Staphylococcus aureus \\
\hline 4 & NG \\
\hline 5 & Staphylococcus aureus \\
\hline 6 & Coagulase-negative Staphylococcus sp \\
\hline 7 & Staphylococcus aureus \\
\hline 8 & Coagulase-negative Staphylococcus sp \\
\hline 9 & Staphylococcus aureus \\
\hline 10 & Staphylococcus aureus \\
\hline 11 & $\begin{array}{l}\text { Staphylococcus aureus } \\
\text { Coagulase-negative Staphylococcus sp }\end{array}$ \\
\hline 12 & Coagulase-negative Staphylococcus sp \\
\hline 13 & $\begin{array}{l}\text { Staphylococcus aureus } \\
\text { Coagulase-negative Staphylococcus sp }\end{array}$ \\
\hline 14 & $\begin{array}{l}\text { Staphylococcus aureus } \\
\text { Coagulase-negative Staphylococcus sp }\end{array}$ \\
\hline 15 & $\begin{array}{l}\text { Staphylococcus aureus } \\
\text { Coagulase-negative Staphylococcus sp }\end{array}$ \\
\hline 16 & $\begin{array}{l}\text { Staphylococcus aureus } \\
\text { Coagulase-negative Staphylococcus sp }\end{array}$ \\
\hline 17 & $\begin{array}{l}\text { Staphylococcus aureus } \\
\text { Coagulase-negative Staphylococcus sp } 20\end{array}$ \\
\hline 18 & Staphylococcus aureus \\
\hline 19 & Staphylococcus aureus \\
\hline 20 & $\begin{array}{l}\text { Staphylococcus aureus } \\
\text { Coagulase-negative Staphylococcus sp }\end{array}$ \\
\hline 21 & $\begin{array}{l}\text { Staphylococcus aureus } \\
\text { Coagulase-negative Staphylococcus sp }\end{array}$ \\
\hline 22 & $\begin{array}{l}\text { Staphylococcus aureus } \\
\text { Klebsiellaoxytoca }\end{array}$ \\
\hline
\end{tabular}


It is also evident from Table 1, that $9(41 \%)$ samples grew more than one organism. Some samples grew different types of coagulase negative Staphylococcus spp., as evident from the difference in their colony morphology, however, they were all reported as coagulasenegative Staphylococcus spp.

This study unveiled an obvious bacterial contamination of the cars' door handles with a considerable number of organism considered to be potential pathogens. This could be attributed to the fact that these door handles are frequently touched by the big number of passengers that depend on these "service" car for transportation within the city. As a considerable number of the microbial skin flora is of Gram-positive bacteria, it would be logical to find them predominant on door handles as previously reported (Nwankwo et al., 2015).

Out of 22 samples processed, 20 (91\%) showed bacterial contamination, a result which is very comparable to that reported by Otter and French in 2009, who observed that $90 \%$ of the hand-touch surfaces in the public transport system and in public areas of a hospital in central London were contaminated by bacteria.

In this study, the most frequently isolated bacterium was Staphylococcus aureus. This result is in full agreement with previous studies as it was also the most frequently isolated bacterium from door handles/knobs of public conveniences (Nworie et al., 2012), door handles of a university (Nwankwo et al., 2015) and internal door handles/knobs of public restrooms (Fakhoury and Nawas, 2018). However, the rate of isolation of this organism $(72.7 \%$ of the samples), in this study, was higher than those previously reported even for the handles/knobs of public restrooms. It was not unexpected to isolate this organism from the "service" door handles, as it can be part of the normal flora of the skin and nostrils of a good proportion of the population and can easily be discharged by several human activities (Cole et al., 2001), however, the rate was definitely higher than expected. Staphylococcus aureus is a potentially pathogenic organism that can cause different types of infections ranging from local infections like abscesses to life threatening systemic infections like meningitis, endocarditis, osteomyelitis, pneumonia and others (Lowy, 1998; Tong et al., 2015).

The second most frequent isolates from the door handles, in this study,were the coagulase negative Staphylococcus spp. isolated from $54.5 \%$ of the samples.Although, these isolates were probably those of Staphylococcus epidermis, which is a member of the normal flora of the skin (Grice et al., 2009; Becker et al.,2014), yet there may have been other coagulase negative Staphylococcus spp., for in the report of Stephenson and his colleagues (2014), the isolated staphylococci from the frequently touched automobile surface interiors were S. epidermidis (43\%), S. aureus (31\%), and S. warneii (13\%). Thecoagulase negative Staphylococcus spp were once considered relatively avirulent and a likely contaminant when isolated from a clinical specimen, these organisms, however, have increasingly been recognized as a cause of clinically significant nosocomial bloodstream infections. Patients at particular risk include those with prosthetic valves, pacemakers, defibrillators, ventricular assist devices, intravascular catheters, or other foreign bodies as well as neonates and immunocompromised hosts. These infections are inherently difficult to treat given the propensity of these organisms to colonize foreign material to form a biofilm and to display resistance to multiple antibiotics (Darouiche, 2004). 
The isolation of $S$. aureus, coagulase negative Staphylococcus spp., Klebsiella spp and other organisms, from the door handles of a university, was previously reported (Nwankwo and Chinyeaka, 2015), and explains the isolation of the Klebsiella oxytoca strain from one of the samples. This micro-organism can be a member of the intestinal flora, but has been a cause of many nososcomial and community acquired infection. It has been associated with urinary, respiratory, biliary tract, skin, and intravascular device (Lin et al., 1997; Sabio et al., 2002).

The results of this study, which demonstrated the presence of potentially pathogenic bacteria on the "service" cars door handles should be taken seriously as all types of passengers use these cars, some who may be the carriers of multiresistant strains of organisms, and others who may be immunocompromised. The organisms contaminating these door handles can colonize individuals and through them be transmitted to others. The best example would be $S$. aureus, which is capable of repeatedly infecting hosts, especially at sites involving the skin (Kaplan, 2005).It is presumed, however, that the bacterial contamination of these door handles is changeable as passengers use them. The organisms that can tolerate a dry environment, like the ones isolated in this study, are the ones that are most likely to persist more on these handles. The absence of bacterial contaminants in two of the samples, however, suggests that the owners, may have resorted to regularly (or at lease before the sampling) clean their cars in a way that prevented colonization by the different bacteria. So regular cleaning practices may be a good strategy to limit colonization by potentially pathogenic microbes, a hypothesis that remains to be tested.

\section{References}

Becker, K., Heilmann, C., Peters, G. (2014). Coagulase-negative staphylococci. Clin Microbiol Rev. 27:870.

Cole, A. M.,Tahk, S., Oren, A., Yoshioka, D., Kim, Y. H., Park, A., Ganz, T. (2001). Determinants of Staphylococcus aureus nasal carriage". Clin Diagn Lab Immunol. 8 (6): 1064-9. doi:10.1128/ CDLI.8.6.1064-1069.2001

Cowan, S.T. and Steel, K.L. Cowan and Steel manual for the identification of medical bacteria. Cambridge University Press, London. 1974.

Dakroub, R. and Nawas, T. Vending machine buttons and touch screens. A surface colonized by pathogenic bacteria. International Journal of Innovative and Applied Research. 5 (5): 82-88 (2017).

Darouiche, R.O. (2004). Treatment of infections associated with surgical implants. N Engl J Med. 350:1422.

Dodrill, L., Schmidt, W.P., Cobb, E., Donachie, P., Curtis, V., and De-Barra M. (2011). The Effect of Hand washing with Water or Soap on Bacterial Contamination of Hands, International Journal Environmental Public Health Resource, 8(1): 97-104.

Fakhoury, S. and Nawas, T. (2018). Contamination of the internal handles/knobs of public restroom doors with potentially pathogenic bacteria. Int. J. Curr. Microbiol. App. Sci. 7(03): 3434 - 3440. DOI: 10.20546/ijcmas. 2018.703.395

Grice, E.A., Kong, H.H., Conlan, S., Deming, C.B., Davis, J., Young, A.C. (2009). Topographical and temporal diversity of the human skin microbiome. Science. 324:1190.

Hamze, F. and Na'was T. (2015). Computer Mice in Public Centers: A Source of Pathogenic Bacteria. ARPN Journal of Science and Technology 5(11): 537-539.

Joshaline, C.M. (2014). Automated teller machine (ATM) - a "pathogen city" - a 
surveillance report from locations in and around Madurai city,Tamil Nadu, India. International Journal of Public Health Science (IJPHS) 3(1):51-56.

Kaplan, S.L. (2005). Treatment of communityassociated methicillin-resistant Staphylococcus aureus infections. Pediatr Infect Dis J. 24:457.

Leyden, J.J., McGinley, K.J., Kaminer, M.S., Bakel, M.J., Nishijima, S., Grove, M.J. and Grove, J.L. (1991). Computerized image analysis of full hand touch plates: A method for quantification of surface bacteria on hands and the effects of antimicrobial agents, Journal of Hospital Infection, 18: 13-22.

Lin, R.D., Hsueh, P.R., Chang, S.C., Chen, Y.C., Hsieh, W.C., Luh, K.T. (1997). Bacteremia due to Klebsiella oxytoca: clinical features of patients and antimicrobial susceptibilities of the isolates. Clin Infect Dis.24:1217-22.

Lowy, F.D. (1998). Staphylococcus aureus infections. New England Journal of Medicine. 339:520-532.

Memišević, S., Jerković-Mujkić, A and Bešta, R. (2013). Bacterial contamination of public telephones in the downtown area of Sarajevo. African Journal of Microbiology Research, 7(17):1664-1667. Nwankwo, E.O. and Chinyeaka, H.A. (2015) Isolation and Identification of Bacterial Contaminants from Door Handles in a Tertiary Institution in Umuahia, Abia State, Nigeria. Nigerian Society of Microbiology, 29: 3139-3147

Nworie, A., Ayeni, J.A., Eze, U.A. and Azi, S.O. 2012. Bacterial contamination of door handles/knobs in selected public conveniences in Abuja metropolis, Nigeria: a public health threat. Continental Journal of Medical Research,
$6(1): 7-11$.

Orskov, I., Orskov, F., Jam, B. and Jann, K. (1997). Serology, chemistry, and genetics of $\mathrm{O}$ and $\mathrm{K}$ antigens of Escherichia coli. Bacteriology Review, 41(3):667-710

Otter, J. and French, G. (2009). Bacterial contamination in touch surfaces in the public transport system and in public areas of a hospital in London. Letters in Applied Microbiology, 49:803-805.

Reynolds, K.A., Watt, P.M., Boone, S.A., and Gerba, C.P. (2005). Occurrence of Bacteria and Bacteria Markers on Public Surfaces. International Journal of Environmental Health Research, 15(3):225-234.

Sabio JM, López-Gómez M, Jiménez-Alonso J. (2002). Spontaneous spondylodiscitis caused by Klebsiella oxytoca. Annals of the Rheumatic Diseases.61:758-759.

Sani, N. M. (2016). Isolation and Identification of Bacterial Contaminants from Door Handles of Public Toilets in FederalUniversity Dutse, Jigawa StateNigeria. IOSR Journal of Pharmacy and Biological Sciences, 11(5), 53-57. doi:10.9790/3008-1105045357.

Stephenson, R. E., Gutierrez, D., Peters, C., Nichols, A., and Boles, B. R. (2014). Elucidation of bacteria found in car interiors and strategies to reduce the presence of potential pathogens. Taylor and Francis Open Select, 30(3), 337-346. doi:10.1080/08927014.2013.873418

Tong S.Y., Davis, J.S., Eichenberger, E., Holland, T.L. and Fowler, V.G. 2015. Staphylococcus aureus infections: epidemiology, pathophysiology, clinical manifestations, and management". Clinical Microbiology Reviews. 28 (3): 603-661. doi:10.1128/CMR.00134-14.

\section{How to cite this article:}

Sleiman Iskandar, Amir Saif and Tarek Nawas. 2018. Isolation of Potentially Pathogenic Bacteria from Public Service Cars Door Handles. Int.J.Curr.Microbiol.App.Sci. 7(12): 1154-1159. doi: https://doi.org/10.20546/ijcmas.2018.712.142 